\title{
Maritime post routes between Corunna and the Caribbean as a Geographic Information System (Gis) model ${ }^{1}$
}

\author{
María Baudot Monroy \\ Department of Modern History, Facultad de Humanidades, Calle Senda del Rey, 7, Madrid, 28040. UNED \\ e-mail: mbaumon@gmail.com
}

Submitted: 3 July 2014. Accepted: 19 April 2015

\begin{abstract}
In 1764, the Secretariat of State created the Maritime Post in order to establish regular, reliable communications with the colonies in the Americas. This was the first in a series of decisive measures which advanced the spread of free trade. The new state service, which came under the Royal Treasury, was designed like a trade route in order to make it self-sufficient. It entailed sending a monthly packet boat to Havana, and from there, documents were distributed throughout the Americas. The logbooks kept by packet boat pilots provide a range of valuable data which make it possible to create a historical GIS.
\end{abstract}

KEYWORDS: Maritime Post boats; logbooks; historical GIS.

Citation / Cómo citar este artículo: Baudot Monroy, María (2015) "Maritime post routes between Corunna and the Caribbean as a Geographic Information System (Gis) model". Culture \& History Digital Journal, 4(2): e021. doi: http:// dx.doi.org/10.3989/chdj.2015.021.

RESUMEN: Los derroteros de los correos maritimos entre La Coruña y el Caribe como modelo de Sistema de Información Geográfica (SIG).- En 1764 la Secretaría de Estado creó los Correos Marítimos para establecer una comunicación regular y fiable con las colonias americanas. Fue la primera de una serie de medidas decisivas que adelantaba la promulgación del Libre Comercio. El nuevo servicio estatal por cuenta de la Real Hacienda se diseñó como una carrera comercial para que fuera autosuficiente. Consistió en enviar un paquebote mensual a La Habana desde donde se repartirían los pliegos por el continente. Los diarios de navegación de los pilotos de los paquebotes aportan valiosos datos de diversa índole que permiten realizar un SIG histórico.

PALABRAS CLAVE: Correos Marítimos; diarios de navegación; SIG histórico.

Copyright: $(2015$ CSIC This is an open-access article distributed under the terms of the Creative Commons AttributionNon Commercial (by-nc) Spain 3.0 License.

\section{INTRODUCTION}

The use of new computer tools (Excel, Access, Filemaker) applied to historical research has brought about the development of new methodology to analysis the data painstakingly gathered together in archives. One of the most useful results, with the most future repercussions, within this complex technological evolution of the processing of data, is historical GIS (Geographic Information Systems). This methodology allows complex historical narratives to be visualized, formed by the interrelation of various data bases with different contents put in relation to geographic space.
GIS is a combination made up of data and computerized methods which allows stored data to be kept, processed, analyzed, transferred and represented, specially relating it spatially to a territory though the connection of maps to a data base. As a result of this union it is possible to visualize a map of information collected in a data base (Burrough, 1998).

Cartographic representations obtained from historical data bases related to a territory and spread in different thematic layers which are interconnected, allows for the visualization, in image form, of a dynamic, historical narrative. This gives a response to the chief demands of spatial History, the historiography method resulting in the 
integration of History with space. Current spatial History is different from normal, traditional historiography in that it is more innovative, interdisciplinary and integrative. The way to arrive at "visualized history" goes through various stages, starting with the availability of original documents and an advanced computer system which allows information to be transferred to a data base so that the finally a GIS is created. This process requires the close collaboration of historians, mathematicians, geographers and computer engineers. The detailed explication about historical GIS, the state of affairs and an up to date bibliography can be found in Crespo Solana (2013: 1-33).

This paper is based the information from the log books of the Maritime Post boats which sailed monthly from Corunna, Spain, to Havana, Cuba, in the second half of the $18^{\text {th }}$ century, in order to create an information data base with multiple fields of concrete information on: dates, boats, routes, layovers, ports, length of voyages, navigational or weather incidents, cargo, captains, crews, merchants and passengers. Subsequently, this complex data base will facilitate the creation of a historic GIS with layers of information. With this GIS a dynamic visualization of all the components and the variables which made up the institution which linked the communication between the mother country and the large area of the Caribbean can be created. To this GIS, on the internal and spatial workings of the Maritime Post between Corunna and Havanna, future data on the expansion of the postal network to other Hispanic Caribbean islands, and later to the American continent can be added. The wide range of routes that the Maritime Postal system eventually covered enabled it to connect areas of the Atlantic with the Pacific though Acapulco and the Manila Galleon trading route, and though its links with the Philippines to Asia as well. This project is a good example of a historic GIS's possibilities, described by Owens (2013: 2014-2040).
The Maritime Post was a complex communication system between the mother country and its colonies, made up of various closely related elements. On the one hand there were the agents: the civil servants of the Postal Service, the captains of the boats, the pilots, the crews, the passengers and the merchants. The boats and everything related to their maintenance, such as shipyards, constitute another element in the system, as do: the ports and their facilities; the post transported in its sacks; goods, money or the postal distribution networks. All these agents and components played their part in various geographic stages: firstly, the starting points of the route. Corunna and Havanna and those who joined it during stopovers and layovers, as well as places which connected it with the rest of the American continent. All these parts of the system formed a wide network of service each contributing to the communication between the far-flung places of the Spanish Empire.

In 1764, the Secretariat of State created the Maritime Post (Correos Marítimos) in order to provide regular, reliable communications with the Indies. It was decided to dispatch an armed xebec under the responsibility of the Royal Treasury (Real Hacienda) to travel from Corunna to Havana each month on a fixed route. The ship was also permitted to carry merchandise and passengers in order to make the new state postal service self-sufficient and profitable. The logbooks kept by the captains of these ships contain a daily account of all information and incidents relating to the voyage. They comprise a series of documents which are highly suitable for building an extensive and varied database. The aim of this paper is to analyze the content of the logbooks from the post boats that covered the Corunna-Havana-Corunna route and evaluate how useful they may be, in terms of the information they provide, for creating a database which can be interpreted and visualized as a historical GIS (Crespo Solana, 2013: 1-33).

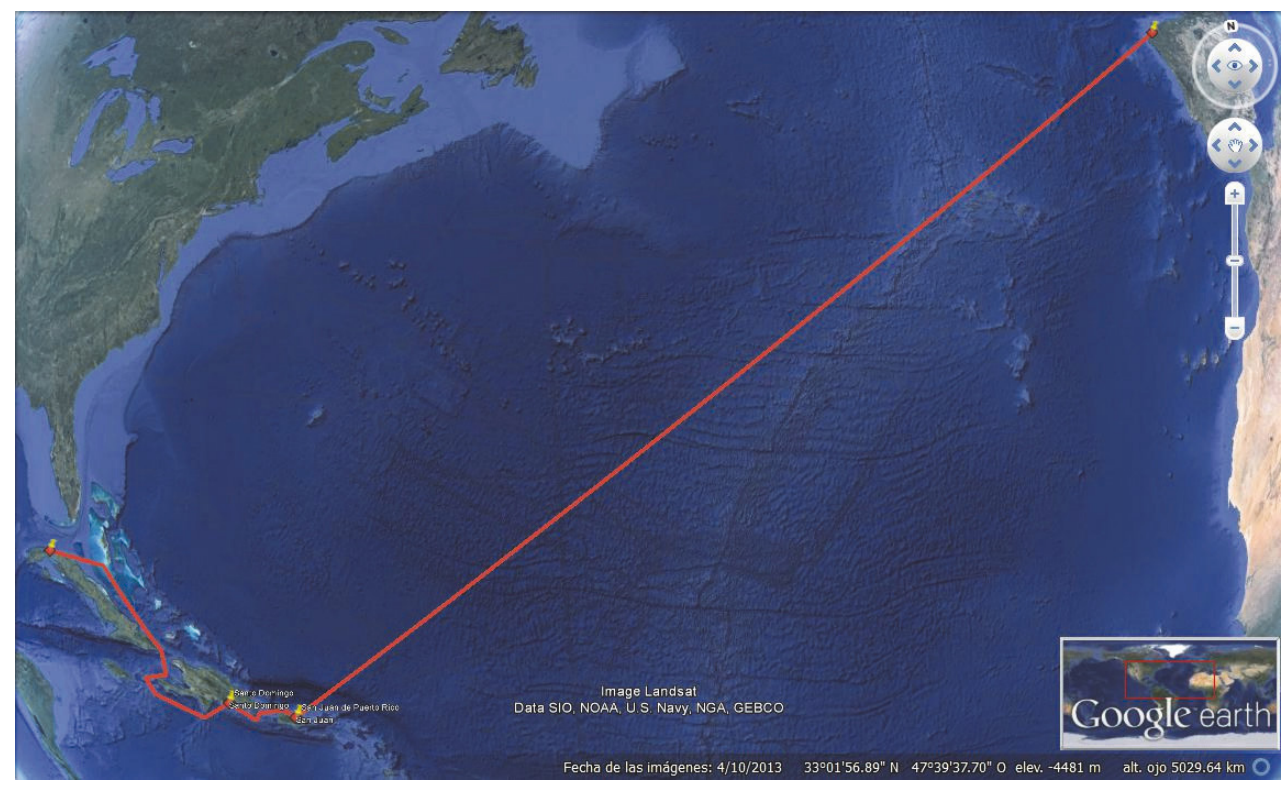

MAP 1. The maritime post route between Corunna and the Caribbean Islands. Source: Self with Google Earth 


\section{ANTECEDENTS TO THE MARITIME POST}

After the discovery of the New World, an administrative organization was formed and put into place to manage the new crown territories and exploit them by means of a system of trade under a monopoly regime: the Carrera de Indias (Route to the West Indies). From the beginning, Spanish institutions had an ongoing interest in maintaining frequent, regular communication with the new colonies in the Americas, until they were lost in the $19^{\text {th }}$ century. This concern is reflected in the many changing regulatory measures enacted to attempt to control the systems of communication set up to connect the two worlds. The office of Postmaster General of the Indies, dispatch boats (navios de aviso) and the Maritime Post were three models for communications which coexisted during the early modern period (Heredia Herrera, 1994: 89-94), along with the ships of the various armadas and merchant ships travelling the Carrera de Indias, which were always willing to serve as go-betweens.

The first mention of dispatch boats is found in a royal order issued by Queen Joanna of Castile and dated May 14th, 1514. It created the position of Postmaster General of the Indies (those "discovered and to be discovered"), appointing Lorenzo Galíndez de Carvajal to the post. This inheritable position was held for life, with obligations that included sending the dispatch boats from Spain to the Indies and back to Spain. Thus, the name of the system came from this role (Veitia Linage, 1672, L.I, cap. 32: $245)$. In 1525 , by another royal order, Charles V created the system of dispatch vessels, which were required to be small, fast boats, assigned exclusively to transporting crates of documents. Subsequent orders regulated various aspects of the dispatch boat voyages, distribution of the documents in the Indies, and the operation of the system itself. These regulations included details of the size and type of vessels used: "they must be long ships of the type built in Sanlúcar and no others." 2 They also established their exclusive function as post boats: "the Indies dispatch boats may not transport gold, silver or goods to the kingdoms, only letters and dispatches entrusted to them, under pain of severe penalties." 3

Although the initial duty of the dispatch boats was to deliver notifications (avisos) of the arrival of the fleets at their destination to the port from which they had departed, they soon began to carry documents from the various governing bodies and institutions, as well as individuals. However, this did not prevent the latter from entrusting their documents to merchant ships in the fleet. The dispatch boats sailed not only with the fleets from Seville, but also alone, and not only from the mother country to the Indies, but also from the colonies to Spain. They came under the Council of the Indies (Consejo de Indias), but dispatch and management was initially the responsibility of the House of Trade (Casa de la Contratación). This body would announce the departure of the next dispatch boat in the city of Seville when it received a dispatch order from the Council. It would contract a ship owner, who would bid to carry out the transport. After 1620, the Mer- chant Guild (Consulado) assumed responsibility for dispatching the boats, by means of successive contacts (asientos) signed with the government, which were renewed over the course of the $17^{\text {th }}$ century and part of the $18^{\text {th }}$ century. This did not prevent the House of Trade from occasionally contracting a private ship owner when the Council of the Indies needed to send an extraordinary dispatch. ${ }^{4}$ The boats were funded by the convoy tax (impuesto de la avería) or special taxes such as the $1 \%$ tax on dispatches (López Bernal, 1996: 27-29; 2011: 18).

Although the transport of goods and passengers was always prohibited, a ban repeatedly expressed in regulations, fraud was common. This was either because it was in the interests of the Royal Treasury or due to ship owners need to finance the voyages, but the reality was that "permissions" were granted, allowing them to carry certain amounts of cargo, which according to López Bernal, never exceeded 100 tonnes. Not only was this regulation not observed, but boats were also unable to keep to a regular timetable, despite the fact that in the 1628 asiento contract, the Merchant Guild had agreed to send four dispatch boats a year, two to Tierra Firme and two to New Spain. The number was gradually increased in successive asiento contracts, until it reached eight boats a year, four to each destination, in the contract signed in 1718. This was ratified in the 1720 contract, which remained in force until the Maritime Post was created in 1764. The service functioned poorly, due to repeated failures on the part of the Merchant Guild to meet dispatch rate and frequency requirements. This was a constant feature which grew worse in times of war (López Bernal, 2011: 28-35).

The lack of regular, smooth communications between the mother country and the colonies had a negative impact on their control and governance because the arrival of news and orders was delayed, with the colonies "often finding themselves forced to make use of foreign colonies to compensate for the lack of news and assistance". It was also harmful to trade on both sides of the Atlantic, as it made it impossible to obtain timely information about markets. And so "the trade of the various territories cannot continue steadily, and the owners in Spain cannot find out the status of their goods", as was stated in the text of the royal decree which announced the creation of the Maritime Post. ${ }^{5}$ Although government leaders and individuals had been able to overcome these inadequate communications somewhat by using the war ships that accompanied the fleets, or naval ships in the $18^{\text {th }}$ century and merchant ships, it was obvious that the system needed comprehensive reform.

\section{CREATION OF THE MARITIME POST IN 1764}

Echoing the extensive criticism and disadvantages produced by the poor operation of the dispatch boats, among others, José del Campillo, in his Nuevo sistema de gobierno para la América (1743), and Bernardo Ward, in his Proyecto económico (1762), openly demanded a reform of the system of communications with the Americas. Both recommended creating established dispatch 
boats that would depart regularly for Havana from a Spanish port, not necessarily Cádiz (Alonso Álvarez, 2012: 43). The reformist atmosphere inspired by the beginning of the reign of Charles III encouraged the submission of reports and petitions offering proposals for improving communications with the Americas. ${ }^{6}$

Of these, we would like to highlight the report prepared by the Count of Campomanes in 1762, when he was adviser to the Mail and Post Revenue Court (juzgado de la Renta de Correos y Postas). His approach is the basis for the proposal for establishing the Maritime Post presented to Charles III by the ministers of a committee convened by the king in January 1764, for the purpose of coming up with solutions to the problem of the inefficient dispatch boats. The committee was headed by Campomanes himself, who was already the public prosecutor of the Council of Castile (Consejo de Castilla). ${ }^{7}$ In his 1762 report, Campomanes praised the British model of weekly postal delivery to its American colonies and recommended setting up a monthly postal system. With the committee's proposal in favour of creating a regular state maritime post service in his hands, in April, Secretary of State Marquis of Grimaldi ordered Campomanes to draft provisional regulations, which the auditor submitted to him in July. On August 6th, a royal decree signed by Charles III was issued, creating the Maritime Post between Corunna and Havana, with monthly departures. On the 24th of the same month, the creation of the new state service was ratified in a royal order.

The new post boat route would be covered by doublemasted corvettes with a single deck, some 100-200 tonnes and 30 metres in length. They were called paquebotes, a term taken from the British "packet boats" due to their function. ${ }^{8}$ Funding was the responsibility of the Royal Treasury. And to make the system profitable, it allowed for the possibility of the ships transporting 60 tonnes of goods, or a maximum of half the ship's tonnage, as well as bringing back riches and passengers. This government initiative represented a breach opened from inside the system in the well-established trade monopoly held by the Cádiz Merchant Guild in the form of the Indies Route. This breach was enlarged by other decisions made by Charles III's ministers during this period, such as the series of direct voyages from Cádiz around the Cape of Good Hope to the Philippines under the charge of the Navy, with the warships also carrying goods and passengers (Cosano Moyano, 1981: 183-220; 1983: 553-569; Martínez Shaw and Alfonso Mola, 2013a: 431-480; 2013b: 307-340). These measures anticipated the first free trade regulations enacted in 1765 (Inglis and Kuethe, 1985: 79-95; Alfonso Mola, 2002: 105-129). A second Maritime Post route between Corunna and Buenos Aires was established in 1767, with regular departures every two months. This consolidated the process of opening up colonial markets to other Spanish cities, slowly bringing an end to the monopoly of the Merchant Guild.

Unsurprisingly, it was not long before there were complaints from Cádiz merchants, supported by the Council of the Indies, opposing the loss of privilege rep- resented by the trade monopoly and termination of the dispatch boat asiento contract that had been in place since 1620 , with minor interruptions. But the appeals lodged were unsuccessful: the decision, which was only part of a larger reform project, had already been made (Vallejo, 1998: 197-262; Herrero Gil, 2008: 127-138). The Reglamento provisional del Correo Marítimo de España y sus Indias Occidentales (Provisional Regulations for the Maritime Post of Spain and its West Indies), written by Campomanes, were passed on August 26th, $1764 .{ }^{9}$ These regulations remained in force until they were replaced by a final version in $1777,{ }^{10}$ to which later provisions were added, first by Floridablanca and then by Godoy. In 1802 , Godoy recommended to Charles IV that the Maritime Post be incorporated into the Navy. This was due to the many packet boats captured during the most recent war with England in the late 1790s, the impossibility of replacing them and the current lack of security at sea due to ongoing military conflict (Cid Rodríguez and López Bernal, 1992: 49-61).

The new Maritime Post was not an exclusive system. Instead, article 19 of the Reglamento regulated the old custom of using naval ships and merchant ships to carry crates of documents at no charge as a complementary alternative system. This provision allowed the House of Trade to continue contracting individual shipowners to dispatch post boats when the Secretariat of the Indies (Secretaría de Indias) or Secretariat of the Navy (Secretaría de la Marina) requested this "due to the requirements of the service" (López Bernal, 2011: 46-58).

The necessary reform was therefore carried out following the Seven Years' War (1756-1763). It was part of the reforms which Charles III implemented to consolidate the Monarchy's position as a military, European and Atlantic power, and make its colonial empire profitable by means of a political and economic reorganization of its existing administrative, military and trade structure (Brading, 2003: 85-126; Kuethe, 2005: 149-159). Government leaders were very aware of the importance of exercising control over colonial officials to ensure compliance with orders so that the reforms could be implemented. They also knew that this control was only possible if there were regular, smooth communications between the colonial territories and the mother country (Lucena, 2010: 37).

\section{THE MARITIME POST HAVANA ROUTE}

The Reglamento written by Campomanes regulated first the Havana route, and after 1767, the Buenos Aires route as well. The latter was created in that year to provide greater efficiency and regularity in communications with the Viceroyalty of Peru. And in terms of trade, it would directly supply the Río de la Plata area from the mother country, carving out a piece of the pie represented by Anglo-Portuguese smuggling through the colony of Sacramento (Alonso Álvarez, 2011: 39-68).

The choice of Corunna as the hub for the postal service - to the detriment of the port of Cádiz - was justified by the government's overall aims, which Campo- 
manes had laid out in his report. These included: the full intention to bring an end to Cádiz's trade monopoly and to the Merchant Guild's asiento contract for dispatch boats discussed earlier, and incorporating ports in the northern part of the mother country into colonial trade and traffic. There was also a desire to take advantage of the cumulative experience of Corunna's port in dispatching post boats bound for Falmouth since 1689 and the existing facilities at La Palloza (shipyard, warehouses, small slipway) (Alonso Álvarez, 2012: 39-68).

The new Maritime Post reported to the Superintendency of Mail and Post (Superintendencia General de Correos y Postas), assigned to the Secretariat of State. The head office was set up at Corunna, and relations with colonial cities were channelled through that office. The main office for the Americas was in Havana, from which the documents were distributed to the rest of the continent, and where they were in turn collected for shipment to Spain each month. A new hierarchical administrative structure was put in place to manage the new institution. In order to integrate the former postal service into the new state service, preventing conflicts of jurisdiction, the crown reclaimed the old postal administration posts sold to individuals, replacing them with elected positions for the main administrators. The process of reclaiming sold positions continued until 1769.

A top-down pyramid of new positions was created for administrative management, beginning with the Postal Superintendent, Secretary of State Grimaldi. On the next tier were the Maritime Post managing directors, one at each hub: Corunna and Havana. Subordinate to them were postal administrators in the ports and cities from which the post was distributed, whose numbers increased as the distribution network expanded, merging with and being extended by the Overland Post. And so the system gradually incorporated cities such as Cádiz and Bilbao on the peninsula, and Veracruz, Buenos Aires, Montevideo and Santiago de Chile in the Americas. José Antonio López and José Antonio Armona were appointed managing directors in Corunna and Havana, respectively. ${ }^{11}$ Orders and instructions were also established for the managing directors in Corunna and Havana, and for the skippers and pilots of the packet boats. Regulations were written governing fees for documents, cargo and passengers (Garay Unibaso, 1987: 51-56)

In April 1764, the decision had already been made to set up the new postal service and Grimaldi had charged Campomanes with writing the provisional regulations with the aim of beginning operations as soon as possible. At that time, Grimaldi asked Pedro González de Castejón, one of the members of the committee that had recommended the creation of the Maritime Post, to take charge of purchasing five ships that would meet the necessary requirements to carry the crates of documents, cargo and some ten passengers. ${ }^{12}$ The purchased ships were refurbished and their hulls were overhauled at the royal shipyard in Zorroza, Vizcaya, which had been selected to build future packet boats under an asiento contract. ${ }^{13}$ It was decided that the small La Palloza shipyard would be

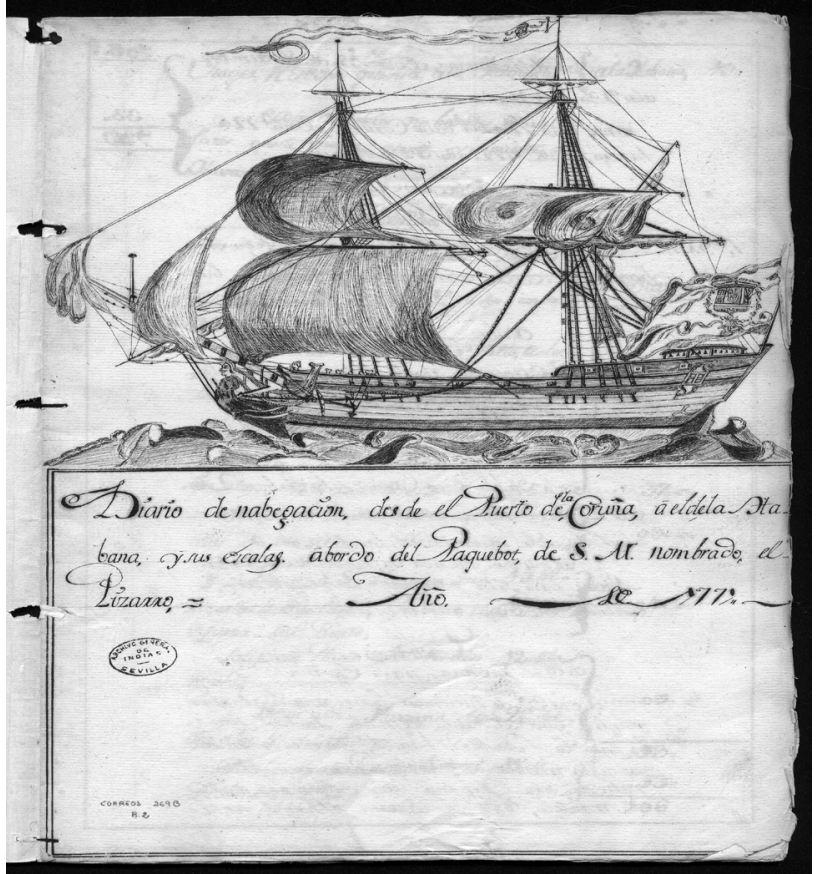

AGI, Correos, 269B, R.2. El Pizarro.

responsible for hull repair and minor refurbishments and repairs necessary before each new sailing. At about the same time, the shipyard at Zorroza was commissioned to build the first xebecs.

In late 1764, November and December, respectively, the packet boats El Cortés and El Pizarro inaugurated the new route, sailing from Corunna to Havana. ${ }^{14}$ From then on, the packet boats set sail from Corunna during the first week of each month with relative regularity, as sailing out of a port always depended on the prevailing wind. However, it was impossible to observe the rule that they should remain only fifteen days in Havana, as the packet boats often required repairs before undertaking the return Atlantic crossing to Corunna.

Experience had shown that another of the causes which delayed the timely departure of a ship within an established period was the ability to complete provisioning in time. In order to avoid such delays in packet boat departures from Corunna, local traders insisted on storing all the necessary parts for four years of ship maintenance at the warehouses at La Palloza, which had been set aside for packet boat supply storage (Herrero Gil, 2006: 653-657).

All employees of the postal service, as well as packet boat captains, pilots and crews, enjoyed special privileges under the Postal Charter (Fuero de Correos) "to prevent the arrest and inconvenience which might be caused by the ordinary and military justice systems". Likewise, the courts of the Indies and the Navy could not interfere "or conduct any investigation" with regard to these vessels and their crews. The aim of these measures, which were contained in the regulations, was to make it clear that nobody, under any circumstances, could detain a postal vessel. 
The new postal system entailed sending a packet boat from the port at Corunna to the port at San Cristóbal de La Habana on the first of each month, following a specific preestablished route. The packet boat was to remain in Havana only some fifteen days, the time believed necessary for provisioning, before setting off on the direct return voyage to Corunna, carrying the crates of documents from the Americas. In order to send mail on to destinations in the Viceroyalty of New Spain, a new subsidiary maritime postal route was established between Havana and Veracruz, calling at Campeche. It used three sloops, one of which was always sailing between the two ports, while the other two remained at the hubs, being prepared for the next journey and loaded with crates and goods. An overland postal network was also created to transport mail from Veracruz to Mexico City and from there to the port of Acapulco, where it was loaded on the galleon headed for Manila.

The government in Madrid wanted to temporarily avoid the expense of setting up another two routes, one between Havana and Cartagena de Indias and the other between Havana and Portobelo, to transport documents and cargo bound for the viceroyalites of Nueva Granada and Peru, respectively. It proposed provisionally establishing a regular overland postal service between Havana and the port of Trinidad, or another alternative in southern Cuba, where the shipments would be loaded onto one of the many merchant ships which travelled regularly between the different ports. Only in the event of being unable to arrange secure, regular service using merchant ships, was the administrator at Havana authorized to purchase two more sloops, one to carry the documents for the Viceroyalty of Peru to Portobelo, and the other to carry those for Tierra Firme to Cartagena. To prevent delays and irregularity, it was not long before this was done. ${ }^{15}$

In this way, the Maritime Post route, which regularly joined the mother country with the colonies, was connected to another three short subsidiary maritime routes, which linked the American hub at Havana with the hubs of the three viceroyalties: Veracruz for Mexico and the Audiencia de Santo Domingo, Cartagena for New Granada and Portobelo for Peru. This created a complex network, connecting the extensive territories of the empire, which grew denser and more complicated as the number of subsidiary cities increased and gradually linked up to the network

From its creation, the communications model initially designed in 1764 showed itself to be ineffective in reaching every corner of the Americas with the same speed and regularity. This was especially true of the most distant areas, such as the Viceroyalty of Peru and the province of Río de la Plata. There was a need to resolve the problem of delays, as well as along with the aim of achieving greater integration among the very distant territories of the empire as a whole and to improve the ability to maintain control from the mother country. Together with the other aims mentioned above, these led to the creation of the Buenos Aires Route in 1767. ${ }^{17}$ The packet boats sailed from Corunna to Montevideo, where mail and goods were unloaded to be transported overland to Buenos Aires (Piniella, 1994: 49-52; Moreno, 2012: 210-231).

The itinerary which the captains were required to follow and other alternative routes, in the event it was not

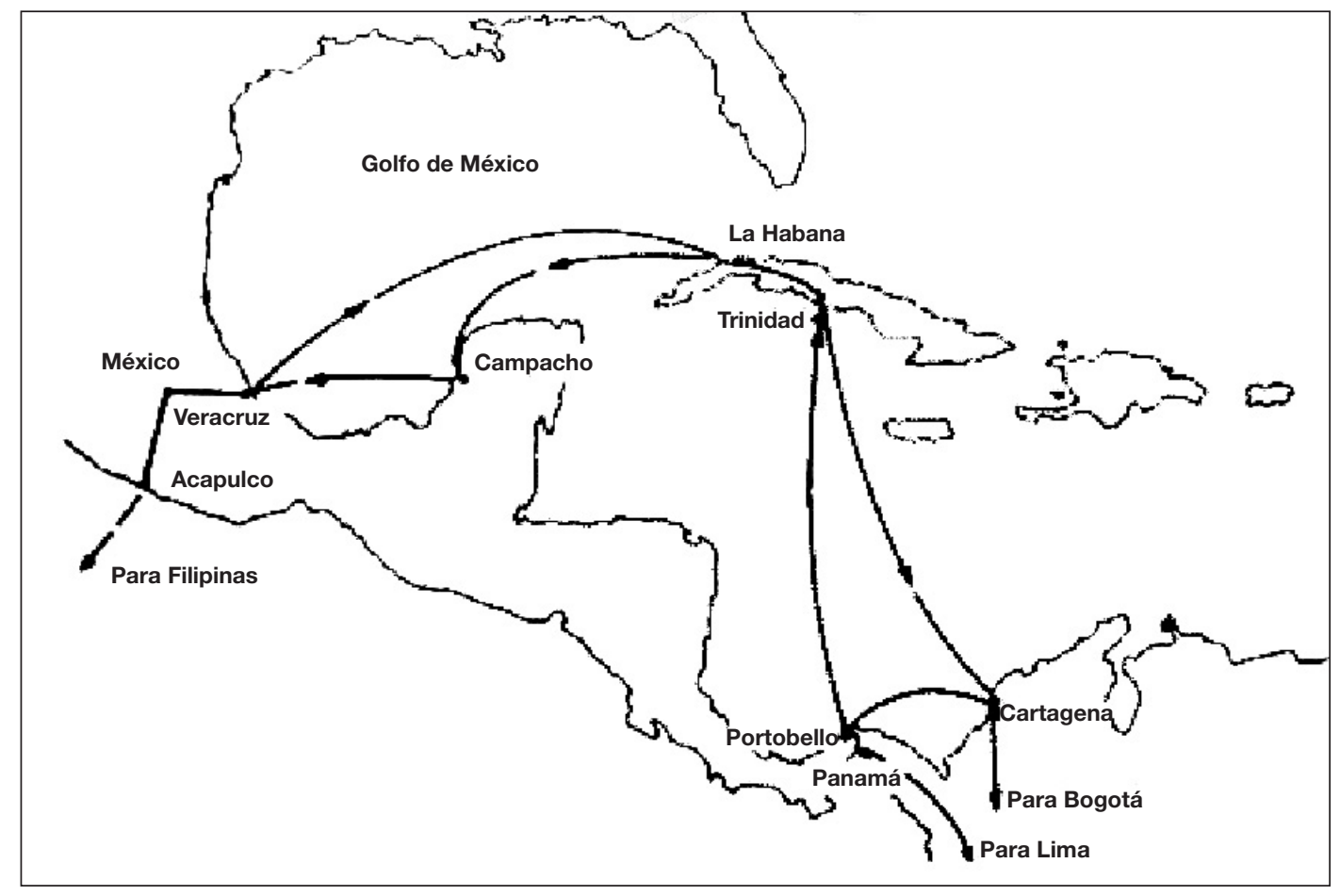

Source: Antonio de Ulloa. Subsidiary Maritime Post routes in the Caribbean according to the 1764 Provisional Regulations. ${ }^{16}$ 
possible to enter the established ports, were described very precisely in the regulations. For packet boats sailing from Corunna to Havana, the first port of call to deliver crates of documents was the port at San Juan, Puerto Rico. However, in the event that the wind made it impossible to enter the inlet, the ship was to head for Aguada de San Francisco (today Aguadilla), located on the northwest side of the island. This was a bay protected from the northern winds, which under similar weather conditions had long served as a refuge where naval ships and the fleets and galleons of the Indies Route could take on water after crossing the Atlantic. The next port of call was the Bay of Montecristi, on the northwestern side of the island of Santo Domingo, near the border with SaintDomingue, the French territory. But if the prevailing winds were from the north, the packet boat captain had two alternatives: the ports of Santo Domingo or Ocoa, on the southern side of the island. If winds were favourable for sailing north, from Montecristi they were to continue on course to Baracoa, at the northeast end of the island of Cuba, where they could take on a pilot (if there was none on board or if their pilot was not familiar with the route through the keys) to cross the Old Bahama Channel, heading west towards the port at San Cristóbal de La Habana. On the other hand, if the prevailing winds were from the north when setting sail from Montecristi, they were to head first to Ocoa and from there to Santiago de Cuba, or Jagua, in southern Cuba, and continue skirting the island, go around Cape San Antonio and head straight for Havana ${ }^{18}$ (Garay, 1987: 65-92).

When they entered the established ports of call, the captains of the packet boat were to announce their arrival with a cannon shot and then wait to hear another in response from the port authorities before unloading the crates. At all ports of call, the ships were only allowed to anchor, and they were only authorized to remain anchored

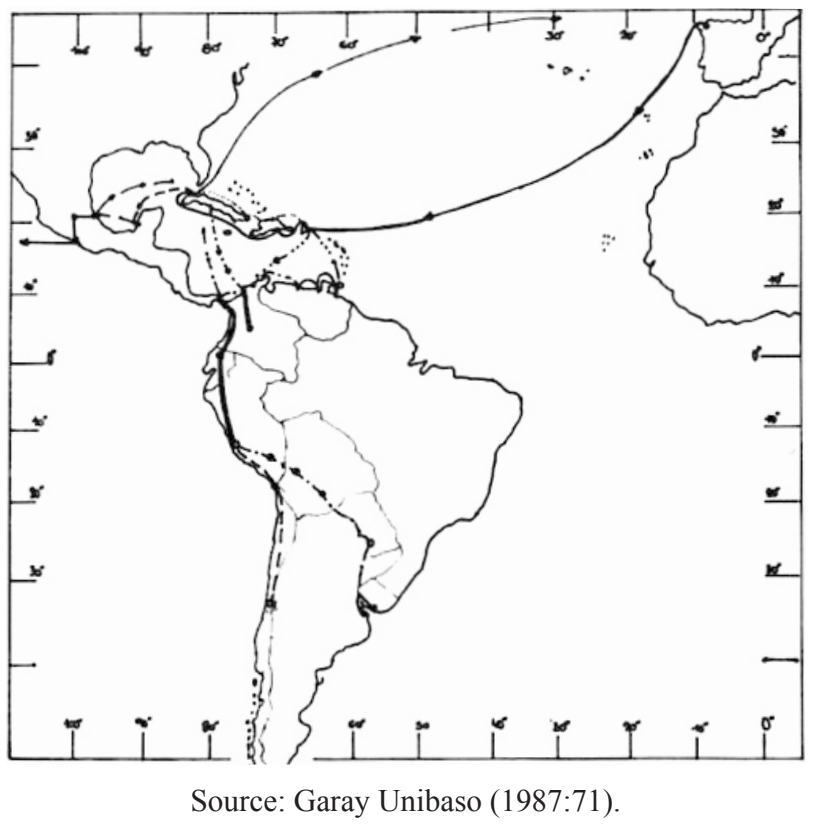

for the time required for the captain personally, or the person designated by him, to unload the crates of documents onto an auxiliary boat and pick up the crates which the port officials had sealed and prepared for collection. On the return voyage from Havana, the boats were expected to sail directly to Corunna.

All the goods loaded onto the packet hat to have their own customs guide and the corresponding duties been paid, even when the sender was the government itself, shipping troops, provisions, seals, sealed paper, tobacco or sugar. Any shipment not complying with this rule would be confiscated. The captain was to carry with him a copy of the goods register, which he handed over to the postal administrator at the port of arrival for verification. Likewise, without exception, all passengers (merchants or persons holding civil or ecclesiastical positions) had to travel under the appropriate permits and pay the same cost of passage as if they were travelling on ships belonging to the Compañía de La Habana or the Compañía Guipuzcoana de Caracas. All fees for the different types of documents and goods freightage were regulated and contained in the regulations.

The plan was for the new service to be self-sufficient and even produce profits for the Royal Treasury. This was why all crates of documents, all goods and all passengers had to pay the corresponding fees, freightage and cost of passage. Once all operating expenses for the voyage and the wages of the employees of the service had been paid out of the funds taken in, the excess amounts were to be brought back to the peninsula on the packet boats. ${ }^{19}$

\section{THE LOGBOOKS}

The pilot was responsible for steering the ship along the plotted route to be followed and determining its position and deviation from this route at any given time. In order to fulfil this duty, he had to determine the four basic elements of navigation; establishing latitude, longitude, destination and distance. To do so, he needed to know the basic principles of practical (when navigating along the coast) and theoretical (the rest of the voyage) navigation. These included: the use of nautical charts and maps, and the ship's compass, cross-staff and chip log. He also had to know the basics of cosmography, astronomy, geometry and trigonometry; know how to use navigation instruments; and have some knowledge of tides, currents, winds and nautical charts and maps. In addition to these aspects of navigation, he was also responsible for the safety of the ship and the goods which had been entrusted to him for transport.

In practice, these obligations translated into the pilot plotting a route on a chart and noting down all navigation data in the logbook every one or two hours: heading, distance travelled in a given interval of time, depth, winds and geographic coordinates of the estimated position, which he would later correct after observing the sun at midday and performing the relevant mathematical calculations. All of this information, plus any observations the pilot considered important, made up a logbook. ${ }^{20}$ 
In the second half of the $18^{\text {th }}$ century, the period when the Maritime Post was created and sailed, determining latitude was relatively easy using the sextant, or much later in the century, the octant. This method took the altitude of the sun at midday as a point of reference. However, calculating longitude was somewhat more difficult. In fact, developing the procedure to calculate longitude accurately was one of the most important scientific achievements of the $18^{\text {th }}$ century. This was first done by using lunar tables and then the chronometers of Harrison, Le Roy and Bertaud. Study of these instruments at naval academies and piloting schools did not become widespread until well into the 1780s, after the American War of Independence (Lafuente, Sellés, 1995: 243-250, 1988: 211-243; González, 2006: 135-166).

Who better than scientist and sailor Jorge Juan y Santacilia to explain what a logbook is:

It is a notebook or book in which an account and details of the ship's voyage are kept, beginning with its departure from port, or from when the anchors are weighed. Every day, notes are made on where it has travelled, where it is located at a given time, near what places it passes, and often, the route to a given point. To this, many add details of common events such as encounters with ships and the sails used. In short, anything which they believe to be useful and curious or which gives an idea of the voyage. A note is also usually made of wind direction and the storms which occurred (...). It is no less essential to make a note of having found a new shoal, safe sources of water, plant life found on them, birds and their breeds. ${ }^{21}$

In fact, the words of Jorge Juan simply compile and explain what was prescribed by the Navy Ordinances, published in 1748, as one of the obligations of the pilot of a vessel:

\footnotetext{
... he shall keep an accurate log of the voyage and in it describe at length the circumstances of its course and the details of the day's run, the type of winds, manoeuvres executed, and in general, all events of the voyage as clearly as possible. ${ }^{22}$
}

The description given by Jorge Juan also contained the method to be used for keeping the log. He begins by pointing out the fact that sailors began counting the hours from midday, continuing until midday of the next day. The purpose of this was to be able to conclude the notes for that day by including an observation of the sun and correcting the ship's "estimated" location should this not coincide with the "observed" location. The latter was the location resulting from measuring the sun's distance following the observation. He also indicated that the best way to note down the information in an orderly manner was by making a table with six vertical columns. The hours would be written in the first column in intervals of two (Ho). In the second column would be noted the miles (M) travelled during each interval of time; in the third, the fathoms of depth (F) obtained from the chip log every two hours; in the fourth, the headings (He) followed by the ship; in the fifth, wind direction (W); and in the sixth, the leeway (L) observed. All of this data was always calculated for the same two-hour time interval. ${ }^{23}$

In accordance with these rules proposed by Jorge Juan for naval pilots and officers, the captains of the postal packet boats also kept their respective logs, with greater or lesser precision, depending on each individual. They introduced a few variations with regard to Jorge Juan's instructions, such as recording the navigation data every hour instead of every two, as he recommended, or including more information by adding more columns to the table. The first regulations from 1764 did not include established rules for gathering data and keeping logs. However, in the 1777 regulations, there were 44 articles devoted to this, including the obligations of captains and pilots, rules for life aboard ship and what action to take in the event of any contingencies (a wreck, death of the captain, etc.), as well as how to keep the logbook. All of these are contained in title II of treatise IV of the 1777 regulations. Below is a transcription of the most important articles referring to logbooks:

\section{Article XI}

In the daily navigation table, the captain and pilot shall make a note of the miles, heading, continued winds and other precepts of the craft every hour (and not every two). At midday, they shall make their regular report, having conducted the observation, indicating whether they have corrected any differences they found and the variation from the ship's compass, which should be done whenever possible.

\section{Article XII}

In their logs, they shall describe in great detail the events of all voyages, the reasons for the main manoeuvres, if the heading was changed for a particular reason, if any dangerous squadron or vessel was seen, and in the proximity of islands and coasts, they will make a note of currents and their direction. In the log, they shall put down the time it takes to put into port, and if they notice anything useful along the course to make it possible to sail with better winds, or any new passage between islands, shoals, channels or soundings, stating for further information the charts or maps used for sailing, with all else dictated by their studies and practical knowledge.

\section{Article XIII}

If an unknown shoal is discovered by accident, they shall try to demarcate it using the latitude and longitude of its location, along with any islands or shoals which are already marked on the charts, but in the incorrect location. They shall also make a note of any other specific and useful information that could be used for steering in the future. And I order that they shall take great pains to put down in their logbooks the appearance or views of any islands, capes and coasts which are not on the printed routes. This service shall be taken into account as appropriate to promote those who most distinguish themselves in it. 
We see that in addition to carrying out the duties of their trade and contract, captains and pilots were also expected to play a role in improving the hydrographic and cartographic knowledge which would help in plotting safe courses for crossings. Likewise, following an old maritime tradition, it was expected that they would train young pilots and sailors with navigation skills in the art of navigation and the knowledge of seamanship.

At the end of the return voyage, packet boat captains were required to hand in their logbook to the managing director in Corunna. Thanks to this practice, they have been preserved, making up a complete series which extends from the first sailings in November and December 1764 to the years $1797-1798$, shortly before the service was incorporated in the Navy in 1802. The series is preserved in the Archivo General de Indias (General Archive of the Indies) in the Correos (Post) section. ${ }^{24}$

The layout of the logbooks which have been consulted matches that proposed by Jorge Juan, with some variations, which can be seen in the examples included below. Each page was reserved for one day's sailing. There was a heading with a phrase something along these lines: "from midday on Saturday the 3rd to midday on Friday the 4th of August". Under the title a table was drown divided into nine columns, rather than the six proposed by Jorge Juan. The twenty-four hours of the day are written in the first vertical column on the left, followed by: miles, measuring the distance travelled each hour; the fathoms to measure depth. The remaining columns contained the headings followed; prevailing winds; leeway, which is the deviation from the heading due to the wind or currents; the quadrant in which the vessel has been sailing; the headings corrected and the cumulative distance. Normally, the pilots made a note of any special aspects they encountered while sailing in the right and bottom margins of the table, along with weather data, the sails they used and a description of the observation of the sun and heading corrections made. Below the table, they drew a box in which they always made a note of the "assumed course", specifying the geographic coordinates of the starting point, which they counted beginning at dawn, and the coordinates of the end point at nightfall. Under the "assumed course" they noted the "corrected course", which was the result of mathematical operations made to determine their position after observing the sun, correcting the ship's heading if the observed position did not coincide with the estimated position.

Not all pilots observed the rules regarding drawing a table and entering the information in it. Some preferred to include all sailing information in a simply written text. But this variation was not common.

Naturally, the writing style of the logs was a very personal matter. Some pilots were very terse and limited themselves to recording the navigation information without adding any additional observations. But there were others who kept very detailed logs with any observations that especially attracted their attention, including information such as a description of the water, or the sea bottom when the water was not very deep. Many of them in-

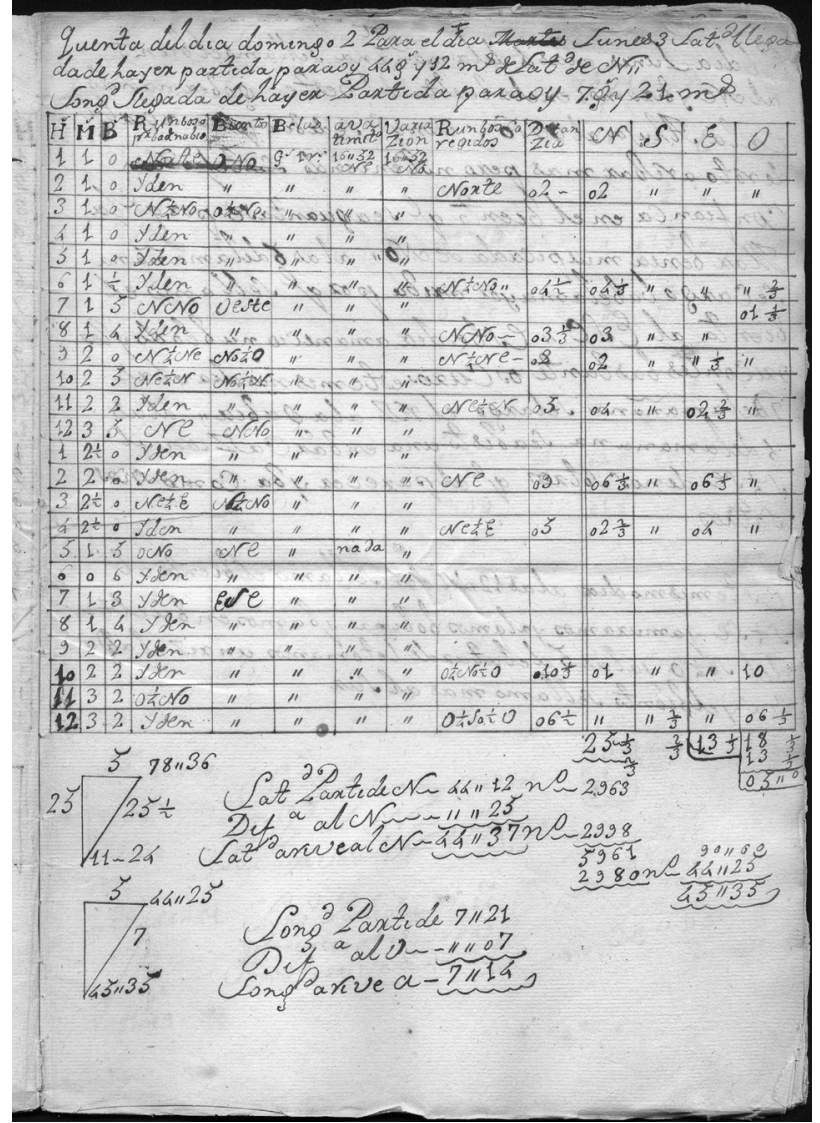

AGI, Correos, 269A, R.1, 5r, image 9.

cluded a wealth of information about weather conditions, describing the skies or the storms. Others drew with words an outline of the landscape they observed from the ship, or specified the sails they used during each interval of time, depending on the prevailing winds. Many captains began their log by giving an account of the packet boat's characteristics, the number of crew members and the armaments carried on board. Others included the routes followed, the ports of call and the days of sailing required for each one. Others commended themselves to God, the Virgin Mary and the saints to whom they prayed. Therefore, in the logbooks a wide variety of information on navigation is found, as well as other matters, according to the arbitrary decision of each author.

Given that the crews of the packet boats were very small (usually only carrying an average of fifteen to twenty men), the captains were in turn the first pilots. They always had a second pilot on board to steer the ship in the event something happened to the captain. Like the ships, which were built at the shipyard in Zorroza, Vizcaya, the vast majority of these sailors were also originally from the northern part of the peninsula, primarily Vizcaya, Guipúzcoa, Cantabria and Asturias (Duo, 2000: 729-745). ${ }^{25}$

The training for these Basque pilots was regulated by Merchant Guild Ordinances and the Bilbao House of Trade. In order to become a qualified ocean-going pilot, 
the candidate was required to study navigation theory for six months with a "skilled and qualified person", generally a teacher at a navigation school, and have completed several training voyages over several years.

Having submitted the relevant certificates issued by the captains of the ships on which he had sailed to the Merchant Guild, the future pilot could present a request to the prior and the consuls to be examined by a competent person designated by them. ${ }^{26}$ To be chosen as the captain or skipper of a ship registered with the Bilbao Merchant Guild, the pilot had to provide proof of having sailed for at least six years as a sailor and two as a qualified pilot.

When selecting the captains of the packet boats, proven experience of having made at least two voyages to the Indies as first pilot was given priority over seniority. ${ }^{27}$

The pilots of the packet boats normally used Dutch nautical charts for navigation. The reference meridian used to calculate longitude was the Tenerife meridian, as it was not until 1884 that a general international agreement was reached, establishing the Greenwich meridian as the zero meridian from which hours were counted..$^{28}$ Therefore, before that time, each nation established its own reference meridian, which was not always the same. Thus, at the beginning of the early modern period, French and Spanish sailors used the meridian that ran through the western part of El Hierro Island for longitude calculations. This was

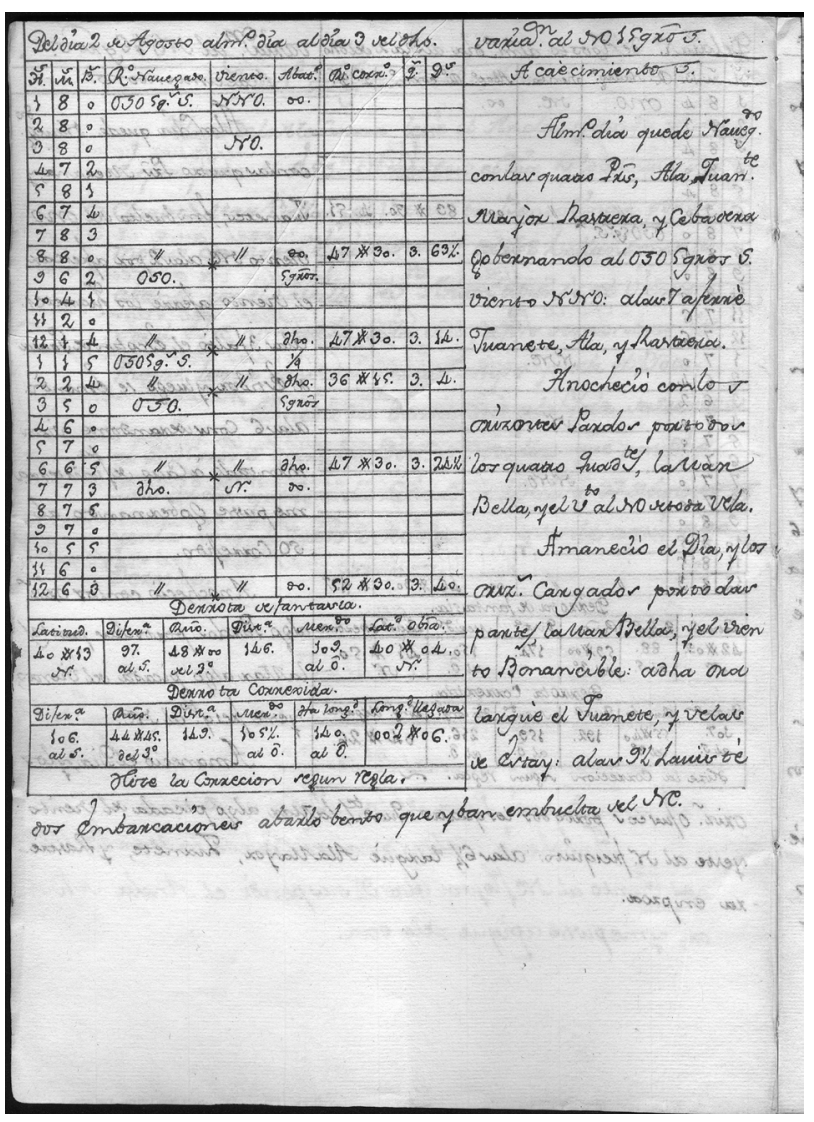

AGI, Correos, 269A, R.4, 6v, image 12. known by all as the "El Hierro meridian", and was later replaced by Tenerife. During the second half of the $18^{\text {th }}$ century, each nation adopted the meridian which ran through the location where it had built its astronomy observatory. Thus, in France it was Paris; in England, Greenwich; and in Spain from the 1780s, it was Cádiz, where the Royal Observatory was situated. The Cádiz meridian replaced Tenerife for the Navy, as well as the merchant navy and Maritime Post (Baron of Ortaffá, 1832: 23-24).

Thus far, the information provided by the logbooks has been discussed. Information such as goods, and transport they do not include must also be mentioned. This information has been collected in other series of documents in the same "Correos" section of the Archivo General de Indias in Seville. This is due to the fact that from the time the Maritime Post was created, it was stipulated that all merchandise must carry its relevant customs "guide" and that all passengers must have their passport. This mode of transport and its repercussions for colonial trade figures still need to be studied. María Dolores Herrero has written a paper on shipments of riches transported by the packet boats whose final destination was Cádiz, which was the hub for colonial trade and the main financial centre in the mother country (Herrero Gil, 2008: 127-138). Recently, Luis Alonso published a valuable study on commercial traffic between Corunna and Buenos Aires and its business links in the economies of Galicia and northern Spain (Alonso, 2012: 39-68). This study offers a regional perspective and it will undoubtedly be necessary to supplement it with studies that have a broader scope.

Finally, it is important to identify the possibility that GIS has additional information which is not in the log books, and which has not been included here or is unknown. For example, how long layovers lastet. A repeated and unjustified longer stay than originally planned at specific port could reveal an irregularity which the captain of the ship tried to hide, such as smuggling which was so common in maritime traffic.

\section{CAN THE INFORMATION PROVIDED BY THE LOGBOOKS BE USED FOR A HISTORICAL GIS?}

Antonio Crespo Sanz defines a GIS as: "a geographic information system made up of computer equipment (computer, screen, scanner, etc.), a specific program (freeware or paid) and a set of geographic data" (Crespo Sanz, 2013: 1-29). Therefore, and as was explained in the introduction, a historical GIS will aim to georeference and visualize a historical narrative by means of a complex interdisciplinary methodology. This makes it possible to relate and connect a wide range of phenomena of all kinds: geographic, economic, biological, socio-political, etc., with the agents involved in or associated with them in some way and with the different area which served as the backdrop. The result is a GIS which will enable us to conduct cross-cutting analyses of historical events and their development, visualizing them in all their dimensions and dynamism, and interconnecting various layers of information (Crespo Solana, 2013: 1-33). 
Beginning with this idea and taking into account the variety of data contained in the logbooks, forming a chronological series over several decades, it is believed that the routes followed by the packet boats can be reconstructed quite accurately and expressed in a geographic field. This would be done based on databases systematically created using the geographic coordinates recorded on a daily basis by the pilots. In other words, these routes can be visualized graphically on a map, applying specifically developed tools and computer languages. It is possible to connect and geographically visualize this first layer of information about the routes followed by the packet boats in the subsidiary maritime and overland networks for mail distribution on the American continent and their evolution as the new state service was consolidated and developed. By doing so, we would obtain a rich and complex image with related cross-information on all the networks that made up the mail distribution routes in the Caribbean, Southern Atlantic and South American continent during the second half of the $18^{\text {th }}$ century.

Additionally, the accumulation of such detailed climatological data as is provided by the logbooks would make it possible to produce a daily reconstruction of the weather over the Atlantic during extended time periods, reconstructing the frequency of Atlantic depressions and tropical hurricanes, periods of drought or prolonged rains. This complex database can also be viewed with the appropriate computing tools. More layers can be added to these first layers of information using data on the goods and passengers transported by the packet boats. Or if we incorporate the agents involved, it would be possible to connect the officials of the different postal departments in the mother country and the Americas, or the captains and crews of the packet boats. Another layer could incorporate a study of the packet boats themselves (construction, maintenance, materials, lifespan, frequency of voyages made).

In this discussion, the possibilities offered by the packet boat logbooks have been considered. However, it would be remiss not to mention that the results of the historical GIS proposed here would be more complete and enhanced by a complementary project of similar characteristics on trade and the passengers transported by the packet boats. There is no doubt that it is possible to visualize a complete historical narrative on the significance of the Maritime Post to the Bourbon reforms of the second half of the $18^{\text {th }}$ century, georeferenced with extensive socio-economic content.

\section{NOTES}

1 This investigation has been coordinated by Prof. Ana Crespo Solana and funded by the MICINN, Reference number HAR2011-27694 and by DynCoopNet Project of the EUROCORES Programm of the European Science Foundation (06-TECT-FP004), cofunded by the National Science Foundation (NSF, USA) and the FCT, Portugal. See: Crespo Solana, Ana \& Alonso García, D. (coords.) Self-organizing Networks and GIS Tools. Cases of Use for the Study of Trading Cooperation (1400-1800); special issue of Journal of Knowledge Man- agement, Economics and Information Technology, June (2012); Mukherjee, Rila (editor), Networks in the First Global Age, 1400-1800, New Delhi: Primus Book, 2011 and Kritz, K; William Cartwright \& L. Lurni, eds., Mapping Different Geographies, Heidelberg: Springer Verlag, 2010.

2 Archivo General de Indias (AGI), Indiferente, 1957, L.4, f.95v-96. Real Cédula, San Lorenzo, 9 September 1587.

3 AGI, Indiferente, 427, L. 30, f. 415v-416r. Real Cédula, 6 October 1589 .

4 AGI, Indiferente, 541, L. 1, f.41v-42. Real Cédula, Madrid, 3 January 1590. "Que los oficiales de la Casa de Contratación paguen con el producto de las averías a la persona designada por el duque de Medina Sidonia 800 ducados para los gastos del apresto de algunos pataches y navíos de aviso".

5 Real decreto, San Ildefonso, 6 August 1764. Quoted by Garay Unibaso, F., 1987:49-51

6 Some projects are in AGI, Correos, 462B

7 AGI, Correos, 462B. Madrid, 1 July 1762. Report of the general directors to Ricardo Wall, 19 July 1762. See López Bernal, 2000a: 62-64 and 2000b: 58-59; 2011: 36-38; Herrero Gil, 2008: 127-138; Vallejo García-Hevia, 1996: 99-179.

8 The name "paquebote" refers not to a tipe of boat but to his function. It comes from the English word packet boat; these were small vesels used to transport mail, goods and passangers between Great Britain and their northamerican colonies.

9 AGI, Correos, 484. Archivo Museo Naval de Madrid (AMNM), Ms. 833 , doc. 14, ff. 129-142.

10 AGI, Correos, 430B. Real Ordenanza del Correo marítimo, aprobada por S.M. en 26 de enero de 1777 y firmada de su mano, impreso. Alcázar Molina, 1920: 233-307.

11 José Antonio Armona went to Havanna in November 1764 with four servents. The passanger's license can be found in AGI, Contratación, 5507, N. 1, R. 24

12 AGI, Correos, 360a. Pedro González de Castejón organiced the purchase of five small frigates, none of them were bigger than 120 tonnes. They had all beeing used as merchant ships in the Baltic Sea. Their price was 255.941 reales de vellón. They were El Pizarro, el Magallanes, el Cortés, el Gallego y el Quirós. In Zorroza they were reformed and made seaworthy, the price of the reforms was 106.212 reales de vellón. Cfr. Rivera Medina, 1996: 119-146.

13 Between 1765 and 1770 In Zorroza were built therteen paquebotes of 100 and 150 tonnes. Cfr. Rivera Medina, 1996: 119-146.

14 AGI, Correos, 269A, R.1. Loogbook of Pizarro. AGI, Correos, 270A, R.1, Loogbook of the Cortés. About the first voyage of the Cortés see, Moreno Cabanillas, 2014: 75-89.

15 Reglamento Provisional del Correo Marítimo de España a sus Indias Occidentales, 1764.

16 Ulloa, A. 2001: 55.

17 AGI, Correos, 17. Contains the documents about the establishment of the maritime post service between La Coruña and Buenos Aires; the previous studies, advises, departures, stopovers, instructions to the captains and pilots, courses and allowed goods, (1767-1781).

18 Reglamento Provisional, articles 7-15.

19 Reglamento Provisional, articles 20 y 21.

20 See Sellés García, M., 2000.

21 Juan y Santacilia, J., 1757: 175.

22 1748, Ordenanzas de S. M. para el gobierno militar, politico y económico de su Armada naval. Primera parte que contiene los asuntos pertenecientes al Cuerpo General de la Armada, en Madrid, en la imprenta de Juan de Zúñiga. Título Segundo, artículos IX-XII: 177-178.

23 Juan y Santacilia, 1757: 177-178.

24 AGI, Correos, 269A-276B. La serie comprende 14 legajos

25 Bañales, G.: Capitanes de Somorrostro en los Correos maritimos (1764-1802). http://somo.blogcindario.com/2009/07/00331-capitanes-de-correo-maritimo-1764-1802-salvo-los-de-somorrostro. html.

26 (1854) Ordenanzas de la ilustre Universidad y Casa de la Contratación de la m.n.y.m.l. villa de Bilbao, París, Librería Garnier hermanos, capítulo XXIV, artículos: LXXIII-LXXVII. 
27 Real Ordenanza del Correo marítimo expedida por S.M: en 26 de enero de 1777, Tratado IV, título II, artículo XXXVII.

28 Archivo General de la Marina "Don Álvaro de Bazán" (AGMAB), leg. 4879, octubre 1884-enero 1885. "Congreso internacional en Washington para la elección del meridiano y la hora cosmopolita"

\section{REFERENCES}

Alcázar Molina, C. (1920) Historia del Correo en América. Biblioteca de Historia Hispanoamericana, Madrid.

Alonso Álvarez, L. (2012) "La sociedad de los Correos Marítimos y sus encadenamientos empresariales en las economías cantábricas, 1764-1802". En Empresas y empresarios en el norte de España (siglo XVIII), editado por Ocampo Suárez-Valdés, J. Ediciones Trea, Gijón: 39-69.

Brading, D. (2003) "La España de los Borbones y su Imperio americano". En Historia e América latina, t. II, editado por Bethell, L. Editorial Crítica, Barcelona: 85-126.

Burrough, P. (1998) Principles of Geographical Information Systems, vol. 333. Oxford University Press, Oxford: 17-33.

Cid Rodríguez, R. (1991) "Los Correos Marítimos a las Indias, una empresa de la Ilustración”. Revista de Humanidades, 2: 50-68.

Cid Rodríguez, R. and López Bernal, J. M. (1992) "El declive de los Correos Marítimos de Indias y su incorporación a la Real Armada". Revista de Humanidades, 3: 49-61.

Cosano Moyano, José (1981) "El comercio directo Cádiz-Manila en navío de la Real Armada (1765-1784)”. In Boletín de la Real Academia de Córdoba, 102, pp. 183-220.

Cosano Moyano, José (1983) "Hombres, mercancías y precios en el tráfico comercial directo entre España y Filipinas en la segunda mitad del siglo XVIII". En Actas del II coloquio de Historia de Andalucía. Andalucía Moderna, Córdoba: 553-569.

Crespo Sanz, A. (2013) "Herramientas y metodología para el análisis de mapas antiguos". Tiempos modernos: Revista Electrónica de Historia Moderna, Monográfico Historia Moderna y Sistemas de Información geográfica, 26 (7): 1-29. http://www. tiemposmodernos.org/search.php.

Crespo Solana, A. (2013) "La Historia geográficamente integrada y los Sistemas de Información Geográfica: concepto y retos metodológicos". Tiempos modernos: Revista Electrónica de Historia Moderna, Monográfico Historia Moderna y Sistemas de Información geográfica, 26 (7): 1-33. http://www.tiemposmodernos.org/tm3/ index.php/tm/article/view/331/373 [consultado 19/marzo/2014].

Duo, G. (2000) "La enseñanza de la Náutica en el País Vasco". Itsas Memoria. Revista de Estudios Maritimos del País Vasco, 3: 729-745.

Garay Unibaso, F. (1987) Correos maritimos españoles a la América española (Yndias occidentales), vol. 1, de 1514 a 1827. Editorial Mensajero, Bilbao.

González González, J. (2006) “Del ‘Arte de marear’ a la navegación astronómica: Técnicas e instrumentos de navegación en la España de la Edad Moderna". Cuadernos de Historia Moderna, Anejos, V: 135-166.

Heredia Herrera, A. (1994) "Los 'Avisos', instrumentos de comunicación y transporte". En Actas del II congreso de Historia de Andalucía y América. Junta de Andalucía y Caja Sur Córdoba.

Herrero Gil, M. D. (2006) "La búsqueda de soluciones en las necesidades del correo marítimo estatal (1764-1802)". En Actas de la IX reunión científica de la Fundación española de Historia Moderna. Málaga: 653-657.

Herrero Gil, M. D. (2008) "El control de las comunicaciones marítimas: el caso particular de la administración de Correos de Cádiz entre 1764 y 1802". Trocadero, 20: 127-138.

Juan y Santacilia, J. (1757) Compendio de navegación para el uso de Caballeros Guardias Marinas. Academy of the Caballeros Guardias Marinas, Cádiz.

Kuethe, J. A. (2005) "Imperativos militares en la política comercial de Carlos III'. En Soldados del Rey. El Ejército borbónico en América colonial en vísperas del a Independencia, editado por Kuethe, J. A. and Marchena. Universidad Jaume I, Castellón: 149-159.
Lafuente, A. and Sellés, M. (1995) "The Problem of Longitude at Sea in the Eighteenth Century in Spain". Vistas in Astronomy, 28: 243-250.

Lafuente, A. and Sellés, M. (1988) El Observatorio de Cádiz, (1753-1831). Ministerio de defensa, Madrid.

López Bernal, J. M. (1996) "Las comunicaciones postales en América durante la época colonial (siglos XVI-XVIII)". En El Correo español en América. Dirección General del Libro, Archivos y Bibliotecas, Ministerio de Obras Pública, Transporte y Medio Ambiente, Madrid: 23-34.

López Bernal, J. M. (2000) "La reforma ilustrada del Correo español: la obra del conde de Campomanes (1755-1768)". Crónica Filatélica, 174, February:.62-64.

López Bernal, J. M. (2000) "La reforma ilustrada del Correo español: la obra del conde de Campomanes (1755-1768)". Crónica Filatélica, 176, April: 58-19.

López Bernal, J. M. (2011) El correo marítimo colonial (17641824). Rutas y tarifas postales. Real Academia Hispánica de Filatelia.

Lucena Giraldo, M. (2010) Naciones de rebeldes: Las revoluciones de independencia americanas. Taurus, Madrid.

Martínez Shaw, C. and Alfonso Mola, M. (2013a) "La Armada en el cabo de Buena Esperanza. La primera expedición del navío Buen Consejo, 1765-1767'. Anuario de Estudios Atlánticos, 59: 431-480.

Martínez Shaw, C. and Alfonso Mola, M. (2013b) "La ruta del Cabo y el comercio español con Filipinas". En Un océano de seda y plata: el universo económico del Galeón de Manila, editado por Bernabéu Albert, S. and Martínez Shaw, C. CSIC, Sevilla: 307-340.

Moreno Cabanillas, R. (2012) "Cartas para administrar desde la distancia. El caso de la Administración de Correos de Cartagena de Indias (1764-1821)". Bibliographica Americana: 210-231.

Ortaffá, Baron of (1832) Principios Generales de Geografia, Matemática o Cosmografia. J. Solá Bookshop, Mayol Press, Barcelona.

Owens, J. B. (2007) "Toward a geographically-integrated, connected world history: Employing geographic information systems (GIS)". En History Compass, 5-6: 2014-2040. doi:10.1111/ j.1478-0542.2007.00476.x

Piniella Corbacho, Francisco (1994) "La organización del tráfico marítimo en Cuba en el siglo XVIII desarrollo de las comunicaciones marítimas y terrestres". Baluarte: Estudios gaditano-cubanos, 1: 49-62.

Rivera Medina, A. (1996) "El astillero real de Zorroza y la Carrera de Indias". En Comerciantes, mineros y nautas, editado por Escobedo Mansilla, R.; Zaballa Beascoechea, A. y Álvarez Gila, O. Universidad del País Vasco, Vitoria: 119-146.

Sellés García, M. (2000) Navegación astronómica en la España del siglo XVIII. Universidad Nacional de Educación a Distancia, Madrid.

Urrutia Zambrana, A, García Rodríguez, M. J., Bernabé Poveda, M. A., Guerrero Nieto, M., (2012) "Geo-History: Incorporation of geographica information systems into historical event studies." In Journal of Knowledge, Management, Economics and Information Technology: Self-organizing Networks and GIS Tools. Cases of Use for the Study of Trading Cooperation, 1400-1800, coordinated by Crespo Solana,Ana and David Alonso García. Scientific Papers: 81-109. http://www.scientificpapers.org/wpcontent/files/Self-organizing Networks 26.06.2012 .pdf [consulted 17/September/2015]

Ulloa, A. de (2001) Modo de facilitar los correos de España con el Reyno del Perú, introduction and preliminary study by Rafael Cid Rodríguez. Padilla Libros, Editores y Libreros, Sevilla.

Vallejo García-Hevia, J.M. (1996) "Campomanes, la biografía de un jurista e historiador (1723-1802)". Cuadernos de Historia del Derecho, 3: 99-179.

Vallejo García-Hevia, J.M. (1998) "Los navíos de aviso y los correos marítimos a Indias (1492-1898)”. Ius Fugit, 7: 197-264.

Veitia y Linage, José de (1672) Norte de la contratación de las Indias occidentales. Juan Francisco de Blas, Sevilla. 